\title{
Pengembangan Paket Modul Cetak Mata Pelajaran Pendidikan Agama Islam (PAI) untuk Siswa SMA Negeri 1 Wangi-wangi Kabupaten Wakatobi
}

\author{
Joko Azis Westomi ${ }^{1}$ \\ Nurdin Ibrahim ${ }^{2}$ \\ Moch. Sukardjo ${ }^{3}$
}

\begin{abstract}
The purpose of this research and development is to produce a package of Islamic religious education print modules, to determine the feasibility of a package of Islamic religious education print modules, and to find out the effectiveness of the Islamic religious education print module package. Modules are used for selfdirected and conventional learning. The research method used is the development method. This study uses the Rowntree development model consisting of three stages of preparation, namely the planning stage, the preparation stage of writing, and the writing and editing stages. Testing the product done to the material experts showed the average score of 4.66 means that the product is considered good, and media experts of 4.79 means the product is considered very good, to students, ie 3 students for the stage face to face with the results of the average score the average of 3.30 means that the product is considered good, and 30 students for the field trial evaluation stage of 4.31 means that the product is considered very good. In conclusion the product can already be said to be good but still there needs to be some improvement in accordance with expert advice, students, and teachers.
\end{abstract}

Keywords: Development and Research, Derek Rowntree Model, Print Module, Islamic Religious Education, High School.

\begin{abstract}
Abstrak: Tujuan penelitian dan pengembangan ini, untuk menghasilkan paket modul cetak pendidikan agama Islam, mengetahui kelayakan paket modul cetak pendidikan agama Islam, dan untuk mengetahui efektivitas paket modul cetak pendidikan agama Islam. Modul dapat digunakan untuk pembelajaran mandiri dan konvensional. Metode penelitian yang digunakan adalah metode pengembangan. Penelitian ini menggunakan model pengembangan Rowntree terdiri dari tiga tahap penyusunan, yakni tahap perencanaan, tahap persiapan penulisan, dan tahap penulisan dan penyuntingan. Ujicoba produk dilakukan kepada ahli materi menunjukkan perolehan skor rata-rata sebesar 4,66 artinya produk dianggap baik, dan ahli media sebesar 4,79 artinya produk dianggap sangat baik, kepada siswa, yakni 3 orang siswa untuk tahap face to face dengan hasil skor rata-rata sebesar 3,30 artinya produk dianggap baik, dan 30 orang siswa untuk tahap field trial evaluation sebesar 4,31 artinya produk dianggap sangat baik. Kesimpulannya produk sudah dapat dikatakan baik namun tetap perlu ada beberapa perbaikan sesuai dengan saran ahli, siswa, dan guru.
\end{abstract}

Kata kunci: Penelitian Pengembangan, Model Derek Rowntree, Modul Cetak, Pendidikan Agama Islam, SMA.

${ }^{1}$ Joko Azis Westomi, Mahasiswa Pascasarjana S2 Teknologi Pendidikan Universitas Negeri Jakarta (UNJ), email: jokomi.10001@yahoo.com. ContakPerson.085397810001

${ }^{2}$ Nurdin Ibrahim, Program Studi Teknologi Pendidikan PPs UNJ

${ }^{3}$ Moch. Sukardjo, Fakultas Teknik Universitas Negeri Jakarta 


\section{PENDAHULUAN}

Fungsi pendidikan nasional, sebagaimana diamanatkan dalam undang-undang nomor 20 tahun 2003 tentang Sistem Pendidikan Nasional pasal 3 adalah mengembangkan kemampuan dan membentuk watak serta peradaban bangsa yang bermartabat dalam rangka mencerdaskan kehidupan bangsa, bertujuan untuk berkembangnya potensi peserta didik agar menjadi manusia yang beriman dan bertakwa kepada Tuhan Yang Maha Esa, berakhlak mulia, sehat, berilmu, cakap, kreatif, mandiri, dan menjadi warga negara yang demokratis serta bertanggung jawab, menuntut adanya proses belajar mengajar yang mampu memfasilitasi siswa untuk mencapai fungsi pendidikan nasional tersebut.

Semangat fungsi pendidikan nasional tersebut merupakan rumusan mengenai kualitas manusia Indonesia yang harus dikembangkan oleh setiap satuan pendidikan. Sumber daya yang berkualitas dan profesional merupakan persyaratan mutlak dalam upaya meningkatkan kualitas bangsa. Bahkan dapat dikatakan bahwa pendidikan adalah tolak ukur kemajuan suatu negara. Negara dapat dikatakan berhasil jika pemenuhan pendidikannya telah mencapai taraf kesuksesan, artinya melalui pendidikan sebuah negara dapat meningkatkan dan mengembangkan kualitas sumber daya manusia yang dimilikinya. Hal ini jelas bahwa tanpa pendidikan sama sekali mustahil suatu kelompok manusia dapat hidup berkembang sejalan dengan aspirasi (cita-cita) untuk maju, sejahtera dan bahagia.

Pesatnya kemajuan ilmu pengetahuan dan teknologi dewasa ini, tentu memberikan dampak yang positif maupun negatif di berbagai segi kehidupan, baik sosial, budaya, ekonomi, termasuk dunia pendidikan. Akibat dari kemajuan ilmu pengetahuan dan teknologi, telah membuka gerbang berbagai macam variasi sumber dan media dalam pembelajaran. Hal ini dilakukan agar peserta didik tidak mengalami kejenuhan dalam mengikuti pelajaran yang di sajikan. Menciptakan pembelajaran yang menyenangkan, merangsang, menantang dan membelajarkan adalah suatu keharusan yang mesti dipenuhi oleh pendidik agar tercipta pembelajaran yang efektif dan efisien. Mengingat pendidikan yang bersifat dinamis dan terus menerus mengikuti perkembangan zaman, maka pembaharuan pendidikan adalah suatu keniscayaan, yang tertuju pada perbaikan situasi dan kondisi belajar dalam meningkatkan pelayanan dan mutu pendidikan itu sendiri.

Untuk mengikuti perkembangan dan kemajuan yang dicapai dibidang ilmu pengetahuan dan teknologi, maka perbaikan pembelajaran erat kaitannya dengan menyediakan mengembangkan serta memanfaatkan aneka sumber belajar, mulai dari yang paling sederhana sampai yang berbasis teknologi maju, serta memberikan kesempatan kepada siswa belajar sesuai dengan kebutuhan dan "gaya" belajarnya. Dengan demikian maka proses pembelajaran menjadi menggairahkan, kreatif, inovatif dan menyenangkan.

\section{Yusufhadi Miarso (2009:}

mengemukakan bahwa pembelajaran adalah usaha pendidikan yang dilaksanakan secara sengaja, dengan tujuan yang telah ditetapkan terlebih dahulu sebelum proses dilaksanakan serta pelaksanaannya terkendali. Artinya bahwa pembelajaran merupakan proses yang dilakukan 
secara sadar berdasarkan tujuan pembelajaran yang telah dibuat sebelumnya sehingga prosesnya berjalan sesuai dengan tujuan yang telah ditetapkan.

Proses pembelajaran menekankan agar bagaimana para peserta didik aktif dan serta dapat berinteraksi dengan pendidik dan sumber belajar agar dapat mengembangkan dan mengoptimalkan potensi yang dimiliki oleh setiap peserta didik dalam suatu lingkungan belajar yang dapat mendukung proses pembelajaran berjalan dengan baik, efektif dan efisien. Dalam mencapai tujuan tersebut siswa berinteraksi dengan lingkungan belajar yang diatur oleh guru melalui proses pembelajaran yang mencakup tujuan pembelajaran, bahan pembelajaran, metodologi pembelajaran, dan penilaian pembelajaran.

Modul merupakan salah satu media atau sumber belajar yang mendorong adanya kemandirian peserta didik yang belajar atau siswa belajar mandiri, artinya bahwa kesadaran dan keaktifan siswa dalam belajar itu menjadi prioritas guru. Guru menjadikan dirinya bukan sebagai satu-satunya sumber ilmu pengetahuan yang harus diterima oleh siswa, dalam konteks ini, guru tidak tampil sebagai "dewa" ilmu pengetahuan yang harus serta merta di terima apa yang diajarkan, tetapi guru tampil sebagai fasilitator belajar siswa. Menurut M. Khoirudin (2016: 112) bahwa modul dapat dimanfaatkan sebagai proses pembelajaran, guna menunjang kompetensi yang harus dimiliki siswa.

Teknologi pembelajaran sebagai sangat tepat diterapkan pada suatu proses desain dan pengembangan yang komprehensif serta digunakan bagi kemandirian belajar peserta didik. Desain merupakan fungsi perencanaan baik secara makro maupun mikro dalam menyiapkan strategi produk. Implikasi desain terhadap pembelajaran di antaranya adalah mengidentifikasi dan membuat spesifikasi dalam penyusunan program atau kurikulum serta modul pembelajaran dan bahan ajar yang diarahkan bagi kepentingan pembelajaran.

Fajar (2016: 224) mengemukakan bahwa guru hendaknya tampil dalam memotivasi dan membimbing siswa untuk menggunakan modul secara disiplin dan berkelanjutan. Dalam pembelajaran di sekolah mulai dari tingkat dasar (TK,SD,SMP atau sederajat) maupun pada tingkat menengah (SMA atau sederajat), tugas utama pendidik adalah bagaimana agar peserta didik yang belajar, dengan cara mengatur dan mengorganisir elemen-elemen inti pembelajaran sedemikian rupa sehingga benar-benar mendukung tercapainya tujuan pembelajaran yang di selenggarkan sebagaimana yang diharapkan, serta dapat memandirikan siswa yang belajar.

\section{Ahmad Munjin Nasih (2009: 7)} mengemukakan bahwa pendidikan agama Islam di samping bertujuan menginternalisasikan nilainilai Islami, juga mengembangkan peserta didik agar mampu mengamalkan nilai-nilai itu secara dinamis dan fleksibel dalam batas-batas konfirgurasi idealitas wahyu Tuhan. Dalam arti, pendidikan agama Islam secara optimal harus mampu mendidik siswa agar memiliki kedewasaan atau kematangan dalam berpikir, beriman dan bertaqwa kepada Allah SWT. Di samping itu juga mampu mengamalkan nilai-nilai yang mereka dapatkan dalam proses pendidikan, sehingga menjadi pemikir yang baik sekaligus mengamalkan ajaran Islam yang mampu berdialog dengan perkembangan kemajuan 
zaman. Abd. Rouf (2015: 18-19) mengatakan bahwa sumber daya guru agama Islam juga perlu terus ditingkatkan kualitasnya, baik dari segi content maupun metodologi. Di samping itu, proses pelaksanaan pendidikan agama Islam harus selalu dilaksanakan dengan baik dan maksimal.

Pendidikan agama Islam mempunyai peran penting dalam pencapaian tujuan pendidikan nasional, maupun untuk mengisi setiap perkembangan ilmu pengetahuan dan teknologi yang selalu berubah seiring dengan perkembangan zaman.

Wakatobi merupakan salah satu daerah pesisir dan terpencil yang ada di Indonesia, tepatnya berada dipulau terujung provinsi Sulawesi Tenggara. Tepat ibu kota kabupaten Wakatobi terletak di pulau wangi-wangi, dibentuk berdasarkan Undang-undang Republik Indonesia Nomor 29 tahun 2003, tanggal 18 Desember 2003. Luas wilayahnya adalah $823 \mathrm{Km}^{2}$ dan pada tahun 2011 berpenduduk 94.846 jiwa dan mayoritas penduduknya adalah beragama Islam.

Dari hasil pra penelitian atau observasi yang di lakukan oleh peneliti selama dua hari, dari tanggal 18-19 April 2016, dengan menggunakan pengamatan, wawancara dan pembagian kuesioner/ angket sebanyak 20 item pernyataan dengan menggunakan jawaban; Sangat setuju, Setuju, Kurang setuju, Tidak setuju dan Sangat tidak setuju. Sampel yang digunakan sebanyak 50 orang siswa kelas X SMA Negeri 1 Wangiwangi. Disimpulkan bahwa rata-rata gambaran pembelajaran pendidikan agama Islam di SMA Negeri 1 Wangi-wangi berada pada kategori skor 3,50 - 4,49 artinya baik, rata-rata motivasi belajar siswa berada pada kategori skor 3,50 - 4,49 artinya baik, dan rata-rata minat/ senang siswa belajar mandiri berada pada kategori skor 3,50 4,49 artinya baik, sedangkan rata-rata tanggapan siswa untuk bahan ajar mandiri berada pada kategori skor 4,50 - 5,00 artinya sangat baik. Hal tersebut dikuatkan dengan hasil wawancara salah seorang guru pendidikan agama Islam yang mengatakan bahwa belum ada modul pembelajaran pendidikan agama Islam untuk di jadikan sebagai sumber belajar siswa SMA Negeri 1 wangi -wangi, dan kami masih mengandalkan buku cetak atau bahan referensi seadanya terutama yang di kirim dari pusat, itupun tidak bisa di pinjamkan ke siswa karena stoknya terbatas, siswa hanya dapat melihat dan membaca di perpustakaan, sehingga kalau seandainya ada sumber referensi lain seperti modul tentu sangat membantu kami dalam mendukung proses pembelajaran terutama pembelajaran pendidikan agama Islam.

Pada sisi yang lain modul menjadi penting untuk dikembangkan dalam penelitian ini, karena pembelajaran pendidikan agama Islam di Kelas X SMA Negeri 1 Wangi-wangi materinya banyak, sementara alokasi waktu yang di berikan sedikit atau terbatas, sehingga membuat materi pembelajaran yang diajarkan tidak maksimal.

Di samping banyaknya materi, alokasi waktu terbatas dan kekurangan sumber belajar, juga SMA Negeri 1 Wangi-wangi mengalami kekurangan guru pendidikan agama Islam. Hal ini dikuatkan dengan hasil wawancara peneliti dengan kepala sekolah SMA Negeri 1 Wangiwangi. Bahwa saat ini jumlah guru pendidikan agama Islam cuma 3 orang yang terdiri 2 orang dari jurusan Tarbiyah (PAI) dan 1 orang dari jurusan Bahasa Arab, mereka mengajar di 20 
kelas yang terdiri dari delapan (8) Kelas X, enam (6) kelas XI dan enam (6) Kelas XII.

Melihat kebutuhan belajar siswa dan keterbatasan sumber belajar, yang ditopang dengan kekurangan guru mata pelajaran pendidikan agama Islam, menjadi daya tarik tersendiri bagi peneliti untuk melakukan penelitian dan pengembangan dalam penelitian ini. Di samping masalah-masalah tersebut, peneliti juga melihat ada kendala umum lain dalam pembelajaran di sekolah yakni keterbatasan mengakses internet, sarana dan prasarana media teknologi dan fasilitas lain yang modern, serta diiringi dengan kendala teknis seperti sering mati lampu.

Oleh karena itu, peneliti menganggap bahwa keberadaan paket modul cetak pendidikan agama Islam sebagai salah satu alternatif untuk mencari jalan keluar dalam mengatasi kesulitan belajar dan mempermudah memfasilitasi siswa untuk belajar.

Gentry dalam Prawiradilaga (2012: 50), mengatakan bahwa pengembangan sebagai pendekatan sistematis bagi rancangan, produk, evaluasi dan implementasi suatu pembelajaran.

Barbara B. Seels (1994: 38) mengungkapkan bahwa pengembangan adalah proses penerjemahan spesifikasi desain ke dalam bentuk fisil. Dalam pengertian ini tidak berarti pengembangan memisahkan diri dari teori dan praktek belajar yang berhubungan dengan, desain, penilaian, pengelolaan dan pemanfaatan sebagaimana yang berada ada kawasan teknologi pembelajaran. Pengertian pengembangan tersebut tidak juga berfokus hanya pada perangkat keras dalam pembelajaran, melainkan juga menyangkut perangkat lunaknya, bahan-bahan visual dan audio, serta program atau paket yang merupakan panduan berbagai bagaian dalam pembelajaran.

Merujuk pada pendapat di atas, maka pengembangan sangat erat kaitannya dengan pembelajaran (Instructional) baik dalam pengembangan produk yang sudah ada maupun menghasilkan produk yang baru, hal ini penting demi tercapainya tujuan pembelajaran yang efektif. Di samping itu pengembangan pembelajaran merupakan upaya meningkatkan kualitas pendidikan melalui pendekatan sistem. Pengembangan dilakukan melalui penerapan prinsip-prinsip ilmiah yang dimulai dari perencanaan, desain, pembuatan, pelaksanaan, dan evaluasi agar tercipta pembelajaran yang efektif dan efisien.

Pada proses pengembangan sangat terkait dengan teknologi pendidikan, artinya pengembangan merupakan suatu bagian terpenting dari teknologi pendidikan yang memiliki potensi cukup besar dalam mengoptimalkan peningkatan pendidikan dengan memanfaatkan faktor-faktor yang tersedia yaitu sarana dan prasarana pada proses pengembangannya. Dengan memfungsikan hubungan antara keterkaitan sistem berbagai sarana maupun prasarana yang tersedia menjadi suatu kesatuan dalam sistem pendidikan akan menghasilkan suatu sistem pendidikan yang dapat mengefisienkan pengembangan pembelajaran.

Menurut Dewi Salma (2012: 50) bahwa kawasan pengembangan adalah proses penerjemahan spesifikasi desain kedalam bentuk fisik. Mencakup banyak variasi teknologi seperti teknologi cetak, teknologi AV, teknologi berbasis komputer, teknologi terpadu. Posisi kawasan pengembangan yang masuk dalam kawasan 
teknologi pembelajaran dapat dilihat pada gambar berikut ini:

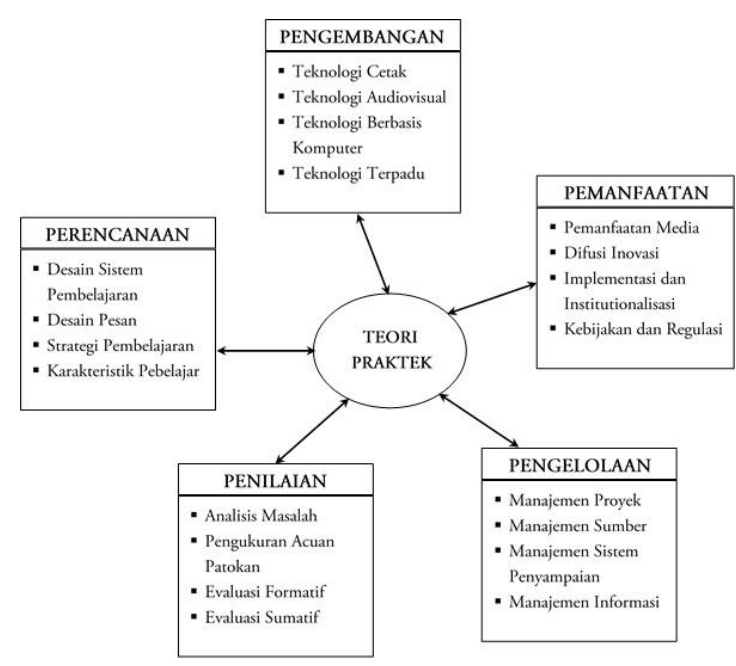

Gambar. 1

Kawasanan Teknologi Pembelajaran

Dalam kawasan teknologi pembelajaran, pengembangan merupakan salah satu domain terpenting dalam mencapai tujuan pembelajaran, di mana pengembangan merupakan proses penerjemahan desain ke dalam bentuk fisik. Hal ini berarti pengembangan mencakup berbagai variasi teknologi yang diterapkan dalam pembelajaran, tetapi tidak terpisah dengan teori dan praktek yang berhubungan dengan belajar dan rancangan serta menunjukkan pada adanya suatu perubahan terkait dengan pembelajaran.

Muhammad Jufni (2015: mengungkapkan bahwa upaya guru dalam pengembangan bahan ajar, dilakukan dengan mendesain dan berkreasi membuat dan menggunakan bahan ajar yang dibutuhkan sesuai dengan materi dan masing-masing sub materi dalam ruang lingkup PAI.

Rancangan paket modul pembelajaran cetak pendidikan agama Islam (PAI) dalam penelitian ini termasuk dalam kawasan pengembangan dalam teknologi pendidikan karena proses rancangan murni mengikuti atau berdasarkan langkah-langkah yang sudah ada, yang dimulai dari analisis kebutuhan sampai pada evaluasi produk yang dihasilkan. Produk yang dimaksudkan adalah paket modul cetak pendidikan agama Islam(PAI) di SMA Negeri 1 Wangi-wangi, Kabupaten Wakatobi.

$$
\text { Meyer dalam Trianto (2009: 21) }
$$

mendefinisikan model sebagai suatu objek atau konsep yang digunakan untuk mempresentasikan sesuatu hal. Sesuatu yang nyata dan dikonversi untuk sebuah bentuk yang lebih komprehensif. Dengan kata lain model juga dapat dipandang sebagai upaya dan untuk mengkonkretkan sebuah teori sekaligus juga merupakan sebuah analogi dan representasi dari variabel-variabel yang dapat di dalam teori tersebut.

Gustafon dan Branch (2002: 13) mengkategorikan model desain pembelajaran ke dalam tiga kategori terkait dengan penggunaannya, yakni: 1). Classroom-Model Oriented, 2) Product-Oriented Models, dan 3) System-Oriented Models.

Model Kemp (2013: 12), masuk dalam kategori classroom oriented models. Model ini terdiri dari 9 tahap yang berkesinambungan satu sama lain sehingga model ini memberikan kebebasan kepada pengembang untuk memulai pada tahap manapun.

Model Hannafin \& Peck dalam I Made Tegeh dkk, (2014: 1) terdiri dari tiga proses utama. Tahap pertama model ini adalah tahap penilaian kebutuhan, dilanjutkan dengan tahap desain dan tahap ketiga adalah pengembangan dan implementasi. Dalam model ini, semua tahapan melibatkan proses evaluasi dan revisi. 
Model ADDIE dalam Benny A. Pribadi (2009: 125), model ini, sesuai dengan namanya, terdiri dari lima fase atau tahapan utama, yaitu $\begin{array}{lll}\text { (A)nalysis, (D)esain, } & \text { (D)evelopment, }\end{array}$ (I)mplementation, dan (E)valuation. Model ini memiliki keunikan tersendiri yaitu menekankan pada manajemen dan memperhatikan keberlanjutan untuk difusi pada hasil.

Model Desain Instruksional Modern, (2014: 131-132) ada tujuh langkah yaitu: Langkah pertama adalah menentukan kebutuhan instruksional dan merumuskan tujuan instruksional umum. Langkah kedua melakukan analisis instruksional. Langkah ketiga mengidentifikasi perilaku dan karakteristik awal peserta didik. Langkah keempat merumuskan tujuan instruksional khusus. Langkah kelima menyusun alat penilaian hasil belajar. Langkah keenam menyusun strategi instruksional. Langkah ketujuh mengembangkan bahan instruksional. Langkah kedelapan mendesain dan melaksanakan evaluasi formatif. Produk akhir dari langkah kedelapan adalah sistem instruksional yang siap diimplementasikan.

Model Rowntree (1994: 5) merupakan model yang didesain untuk menghasilkan sebuah produk pembelajaran, misalnya penulisan modul. Menurut Rowntree, dalam mengembangkan bahan ajar terdapat tiga tahapan, yaitu tahap perencanaan, persiapan penulisan, serta penulisan dan penyuntingan.

Sri Haryati (2012: 24) mengungkapkan bahwa secara empirik langkah penelitian dan pengembangan dapat dikemas dan disederhanakan menjadi 4 tahapan yaitu: Pendahuluan, pengembangan, validasi, dan pelaksanaan.
Khairi Abu Syairi (2013: 65) mengungkapkan bahwa bahan ajar merupakan seperangkat materi atau substansi pelajaran yang disusun secara runtut dan sistematis serta menampilkan sosok utuh dari kompetensi yang akan dikuasai siswa dalam kegiatan pembelajaran.

Menurut Purwanto, dkk ( 2007: 9) modul ialah bahan belajar yang dirancang secara sistematis berdasarkan kurikulum tertentu dan dikemas dalam bentuk satuan pembelajaran terkecil dan memungkinkan dipelajari secara mandiri dalam satuan waktu tertentu. Dewi Salma Prawiradilaga (2012: 9) mengungkapkan bahwa modul adalah bahan ajar yang dirancang untuk belajar mandiri. Nurdin Ibrahim (2010: 137) mengemukakan bahwa modul merupakan salah satu bahan belajar baik mandiri maupun konvensional yang dirancang secara sistematis, terarah, dan terukur untuk mencapai tujuan pembelajaran. Andi Prakoso (2015: 106) mengemukakan bahwa modul adalah sebuah bahan ajar yang disusun secara sistematis dengan bahasa yang mudah dipahami oleh peserta didik sesuai tingkat pengetahuan dan usia mereka, agar mereka dapat belajar sendiri (mandiri) dengan bantuan atau bimbingan yang minimal dari pendidik. Berbeda dengan definisi sebelumnya B.P. Sitepu (2006: 133) berpendapat bahwa modul pada hakikatnya merupakan media yang dapat disusun dan dipergunakan untuk keperluan pembelajaran konvensional dan keperluan pembelajaran mandiri. Secara singkat modul dapat diartikan sebagai unit terkecil bahan pelajaran yang memuat suatu konsep secara utuh sehingga dapat dipelajari secara terpisah dari bagian lain tanpa mengurangi makna. 
M. Khoirudin (2016: 112) mengemukakan bahwa modul dapat dimanfaatkan sebagai proses pembelajaran, guna menunjang kompetensi yang harus dimiliki siswa"

Eko Budiono (2006: 87) mengungkapkan bahwa cara yang makin baik dalam menggunakan modul adalah siswa aktif mempelajarinya bersama dengan rekan kerja sementara guru melakukan pengecekan secara intensif dan memberikan bantuan kepada siswa yang mengalami kesulitan dalam mempelajari modul secara individual.

Izkar Hadiya, dkk, (2015: 90) mengungkapkan bahwa modul dapat menciptakan pembelajaran aktif dengan pendekatan ilmiah walaupun peran guru dan ketersediaan fasilitas pendukung masih sangat diperlukan agar pembelajaran terlaksana dengan baik.

Ambar Sri Lestari (2014: 175-176) mengungkapkan bahwa "Penggunaan modul didasarkan pada fakta bahwa jika peserta didik diberikan waktu dan kondisi belajar memadai maka akan menguasai suatu kompetensi secara tuntas. Bila peserta didik tidak memperoleh cukup waktu dan kondisi memadai, maka ketuntasan pelajaran akan dipengaruhi oleh derajat pembelajaran. Kesuksesan belajar menggunakan modul tergantung pada kriteria peserta didik didukung oleh pembelajaran tutorial. Kriteria tersebut meliputi ketekunan, waktu untuk belajar, dari pembelajaran, mutu kegiatan pembelajaran, dan kemampuan memahami petunjuk dalam modul."

Fajar Lailatul Mi'rojiyah (2016: 224) mengungkapkan bahwa "guru hendaknya tampil dalam memotivasi dan membimbing siswa untuk menggunakan modul secara disiplin dan berkelanjutan" Menurut Haris Mujiman (2011: 9) belajar mandiri adalah kegiatan belajar aktif, yang didorong oleh niat atau motif untuk menguasai sesuatu kompetensi guna mengatasi sesuatu masalah, dan dibangun dengan bekal pengetahuan atau kompetensi yang telah dimiliki.

Mata pelajaran pendidikan agama Islam merupakan salah satu mata pelajaran yang diajarkan di SMA secara terpisah. Mata pelajaran pendidikan agama Islam banyak diminati siswa terutama yang beragama Islam, karena di samping memperakaya wawasan ilmu pengetahuan, juga dapat memperkuat spiritual keimanan dalam menjalankan hubungan vertikal dengan Tuhannya, dan dapat memperbaiki etika dalam membangun hubungan horizontal antara anak dan orang tuanya ataupun sesama teman (orang lain), serta dapat mencerminkan jiwa integritas dan moralitas pada diri siswa dalam kehidupan sehari-hari.

\section{METODOLOGI}

Penelitian dan pengembangan ini bertujuan antara lain : Pertama untuk menghasilkan sebuah produk yang berupa paket modul cetak pembelajaran pendidikan agama Islam untuk siswa kelas X SMA, kedua untuk mengetahui kelayakan paket modul cetak pendidikan agama Islam untuk siswa kelas X SMA, dan ketiga untuk mengetahui efektivitas paket modul cetak pendidikan agama Islam untuk siswa kelas $\mathrm{X}$ SMA. Modul dikemas dalam bentuk cetak yang dapat digunakan untuk pembelajaran mandiri maupun konvensional. Penelitian ini juga memberikan gambaran yang menyeluruh dan mendetail mengenai proses pengembangan modul 
pendidikan agama Islam (PAI) yang dikembangkan.

Penelitian ini dilakukan di SMA Negeri 1 Wangi-wangi, Kab. Wakatobi, Provinsi Sulawesi Tenggara. Penelitian ini dimulai dari bulan Mei 2016 sampai dengan bulan September 2017, yang terdiri dari tahapan penyususnan rencana penelitian hingga penyusunan laporan penelitian.

Dilihat dari tujuannya yaitu mengembangkan paket modul cetak pembelajaran pendidikan agama Islam untuk siswa kelas $\mathrm{X}$ SMA, maka penelitian ini dapat dikatakan sebagai penelitian pengembangan (Research and Development). Sugiyono (2015: 297) metode penelitian dan pengembangan adalah metode yang digunakan untuk menghasilkan produk tertentu, dan menguji keefektifan produk tersebut.

Pendekatan yang dilakukan dalam penelitian dan pengembangan ini adalah pendekatan pengembangan pembelajaran berorientasi pada produk dengan menggunakan model pengembangan Derek Rowntree. Pendekatan ini dilakukan karena diawali dengan mengkaji permasalahan dengan melakukan analisis kebutuhan pembelajaran di sekolah untuk menentukan perlu atau tidaknya paket modul pembelajaran cetak. Secara umum Model Rowntree ini terdiri dari 3 tahap yaitu 1) Perencanaan; meliputi (a) menganalisis peserta didik, (b) merumuskan tujuan pembelajaran, (c) membuat garis besar isi, (d) menentukan media, (e) merencanakan pendukung belajar, (f) mempertimbangkan bahan ajar yang ada; 2) persiapan penulisan; meliputi: (a) mempertimbangkan sumber dan hambatan, (b) mengurutkan ide atau gagasan penulisan, (c) mengembangkan aktifitas dan umpan balik, (d) menentukan contoh-contoh yang terkait, (e) menentukan ilustrasi lainnya, (f) menentukan peralatan tambahan yang dibutuhkan, (g) merumuskan format fisik; dan 3) penulisan dan penyuntingan, meliputi ; (a) mulai membuat draft, (b) melengkapi draft dan penelaahan, (c) menulis asesmen belajar, (d) menguji coba bahan ajar, (e) memperbaiki bahan ajar.

\section{HASIL DAN PEMBAHASAN}

\section{Hasil}

Hasil penelitian dan pengembangan ini, peneliti terlebih dahulu melakukan analisis kebutuhan, merumuskan tujuan umum dan tujuan khusus, menyususn garis besar isi, menetukan media, merencanakan pendukung belajar, mempertimbangkan bahan ajar yang ada, mempertimbangkan sumber-sumber dan hambatannya, mengurutkan ide dan gagasan, mengembangkan aktifitas dan umpan balik, menetukan contoh-contoh yang terkait, menentukan ilustrasi lainnya, menentukan peralatan tambahan yang dibutuhkan, merumuskan format fisik, mulai membuat draft, melengkapi draft dan penelaahan, menulis asesmen belajar, dan terakhir mengujicoba bahan ajar.

Peneliti mengujicoba produk yakni paket modul cetak mata pelajaran pendidikan agama Islam untuk siswa kelas X SMA, dimulai dari validasi ahli materi yakni Dr. Syamsi Setiadi, M. Pd dan ahli media yakni Dr. Robinson Situmorang, M. Pd, dengan menggunakan kuesioner.

Hasil penilaian dari validator ahli materi direkap dan hasilnya dipaparkan pada tabel berikut: 
Tabel 1. Rekapitulasi Ahli materi

\begin{tabular}{|c|c|}
\hline Komponen & $\begin{array}{l}\text { Rata-rata } \\
\text { Penilaian }\end{array}$ \\
\hline Desain Pembelajaran & 4,70 \\
\hline 1. Tujuan pembelajaran & 5 \\
\hline 2. Metode pembelaran & 4,29 \\
\hline 3. Contoh & 4,5 \\
\hline 4. Evaluasi & 5 \\
\hline Kelayakan Isi & 4,89 \\
\hline 1. Kebenaran Konsep & 4,8 \\
\hline 2. Urutan Konsep & 5 \\
\hline $\begin{array}{l}\text { Prinsip Desain Pesan } \\
\text { (Verbal) }\end{array}$ & 4,76 \\
\hline 1. Bahasa & 4,75 \\
\hline 2. Struktur Kalimat & 5 \\
\hline 3. Simbol atau Istilah & 4 \\
\hline Rata-rata & 4,66 \\
\hline
\end{tabular}

Berdasarkan hasil ujicoba yang dilakukan terhadap ahli materi diperoleh skor rata-rata 4,66. Hasil ini menyatakan bahwa modul pendidikan agama Islam (PAI) yang dikembangkan dari segi materi yang meliputi desain pembelajaran, kelayakan isi dan prinsip desain pesan verbal sudah sangat baik.

Tabel 2. Rekapitulasi Ahli Media

\begin{tabular}{|c|c|}
\hline \multicolumn{1}{|c|}{ Komponen } & $\begin{array}{c}\text { Rata-rata } \\
\text { Penilaian }\end{array}$ \\
\hline Komponen Modul & $\mathbf{5}$ \\
\hline Ukuran & $\mathbf{5}$ \\
\hline Prinsip Desain Pesan Visual & 4,77 \\
\hline 1. Tata Letak & 4,44 \\
\hline 2. Tipografi & 4,85 \\
\hline 3. Ilustrasi & 4,72 \\
\hline 4. Warna & 5 \\
\hline 5. Pencetakan & 4,72 \\
\hline Rata-rata & $\mathbf{4 , 7 9}$ \\
\hline
\end{tabular}

Berdasarkan hasil ujicoba yang dilakukan tehadap ahli media diperoleh skor rata-rata 4,79. Hasil ini menyatakan bahwa pendidikan agama Islam (PAI) yang dikembangkan dari segi media yang meliputi komponen modul, ukuran modul dan prinsip desain pesan visual sudah sangat baik.
Tabel 3. Rata-rata nilai Ujicoba Face to Face

\begin{tabular}{|l|c|c|c|}
\hline \multirow{2}{*}{ Komponen } & \multicolumn{3}{|c|}{ Nilai Rata -rata } \\
\cline { 2 - 4 } & Tinggi & Sedang & $\begin{array}{l}\text { Renda } \\
\text { h }\end{array}$ \\
\hline $\begin{array}{l}\text { Desain } \\
\text { Pembelajaran }\end{array}$ & $\mathbf{4 , 2 8}$ & $\mathbf{3 , 2 8}$ & $\mathbf{2 , 5 5}$ \\
\hline $\begin{array}{l}\text { 1. Metode } \\
\text { Pembelajaran }\end{array}$ & 4 & 3 & 2 \\
\hline 2. Contoh & 4,33 & 3,33 & 2,66 \\
\hline 3. Evaluasi & 4,5 & 3,5 & 3 \\
\hline $\begin{array}{l}\text { Fungsi dan } \\
\text { Ukuran Modul }\end{array}$ & $\mathbf{3 , 6 7}$ & $\mathbf{3 , 3 3}$ & $\mathbf{2 , 6 7}$ \\
\hline $\begin{array}{l}\text { Prinsip Desain } \\
\text { Pesan Verbal }\end{array}$ & $\mathbf{3 , 6 3}$ & $\mathbf{3 , 1 3}$ & $\mathbf{2 . 6 3}$ \\
\hline 1. Bahasa & 3,75 & 3,25 & 2,75 \\
\hline $\begin{array}{l}\text { 2. Struktur } \\
\text { Kalimat }\end{array}$ & 3,5 & 3 & 2,5 \\
\hline $\begin{array}{l}\text { Prinsip Desain } \\
\text { Pesan Visual }\end{array}$ & $\mathbf{4}$ & $\mathbf{3 , 4 2}$ & $\mathbf{2 , 7 1}$ \\
\hline $\begin{array}{l}\text { 1. Tata } \\
\text { Letak/Layout }\end{array}$ & 3,83 & 3,33 & 2,67 \\
\hline 2. Tipografi & 4,14 & 3,43 & 2,71 \\
\hline 3. Ilustrasi & 3,83 & 3,33 & 2,67 \\
\hline 4. Warna & 4,2 & 3,6 & 2,8 \\
\hline \multicolumn{1}{|c|}{ Rata-rata } & $\mathbf{3 , 9 7}$ & $\mathbf{3 , 3 0}$ & $\mathbf{2 , 6 4}$ \\
\hline $\begin{array}{l}\text { Rata-rata } \\
\text { Keseluruhan }\end{array}$ & & $\mathbf{3 , 3 0}$ & \\
\hline
\end{tabular}

Berdasarkan hasil ujicoba yang dilakukan terhadap tiga orang siswa diperoleh skor rata-rata keseluruhan 3,30. Hasil ini menyatakan bahwa modul cetak fisika yang diproduksi dari segi desain pembelajaran, fungsi dan ukuran modul, prinsip desain pesan verbal dan visual sudah baik.

Tabel 4. Rata-rata nilai Ujicoba Field Test

\begin{tabular}{|c|c|}
\hline Komponen & $\begin{array}{c}\text { Nilai } \\
\text { Rata-rata }\end{array}$ \\
\hline Desain Pembelajaran & 4,26 \\
\hline 1. Metode Pembelajaran & 4,23 \\
\hline 2. Contoh & 4,27 \\
\hline 3. Evaluasi & 4,57 \\
\hline Fungsi dan Ukuran Modul & 4,42 \\
\hline Prinsip Desain Pesan Verbal & 4,31 \\
\hline 1. Bahasa & 4,22 \\
\hline 2. Struktur Kalimat & 4,4 \\
\hline Prinsip Desain Pesan Visual & 4,27 \\
\hline 1. Tata Letak & 4,17 \\
\hline 2. Tipografi & 4,35 \\
\hline 3. Ilustrasi & 4,34 \\
\hline 4. Warna & 4,27 \\
\hline Rata-rata & 4,31 \\
\hline
\end{tabular}


Berdasarkan hasil ujicoba yang dilakukan terhadap 30 (tiga puluh) orang siswa diperoleh skor rata-rata keseluruhan $\mathbf{4 , 3 1}$. Hasil ini menyatakan bahwa pendidikan agama Islam (PAI) yang dikembangkan dari segi desain pembelajaran, fungsi dan ukuran modul, prinsip desain pesan verbal dan visual sudah sangat baik.

Tabel 5. Rata-rata Hasil Uji Keterbacaan Cloze Test

\begin{tabular}{|l|c|}
\hline \multicolumn{1}{|c|}{ Modul atau Pokok Bahasan } & $\begin{array}{c}\text { Nilai } \\
\text { Rata-rata }\end{array}$ \\
\hline $\begin{array}{l}\text { Kegiatan Belajar 1 } \\
\text { (Manusia dan Peranannya di } \\
\text { Bumi) }\end{array}$ & $75.61 \%$ \\
\hline $\begin{array}{l}\text { Kegiatan Belajar 2 } \\
\text { (Perilaku Ikhlas dalam } \\
\text { Beribadah) }\end{array}$ & $77.19 \%$ \\
\hline $\begin{array}{l}\text { Kegiatan Belajar 3 } \\
\text { (Sifat Allah dalam Asma'ul } \\
\text { Husna) }\end{array}$ & $77.65 \%$ \\
\hline $\begin{array}{l}\text { Kegiatan Belajar 4 } \\
\text { (Perilaku Husnuzzan) }\end{array}$ & $80.12 \%$ \\
\hline $\begin{array}{l}\text { Kegiatan Belajar 5 } \\
\text { (Hukum Islam) }\end{array}$ & $81.93 \%$ \\
\hline $\begin{array}{l}\text { Kegiatan Belajar 6 } \\
\text { (Sejarah Rasulullah SAW, di } \\
\text { Mekah) }\end{array}$ & $\mathbf{7 8 . 5 8 \%}$ \\
\hline Rata-rata
\end{tabular}

Dilihat dari tabel di atas, dapat diketahui bahwa wacana atau bahan bacaan yang terdapat pada modul Pendidikan Agama Islam (PAI) yang dikembangkan untuk siswa SMA diperoleh ratarata keseluruhan 78,58\%. Dapat dirinci, untuk modul Kegiatan Belajar 1 pokok bahasan Manusia dan Perannya di Bumi mencapai $75.61 \%$, Kegiatan Belajar 2 dengan pokok bahasan Perilaku Ikhlas dalam Beribadah mencapai persentase $77.19 \%$, Kegiatan Belajar 3 dengan pokok bahasan Sifat Allah dalam Asma'ul Husna mencapai $77.65 \%$, Kegiatan Belajar 4 dengan pokok bahasan Perilaku Husnuzzan mencapai
$78.94 \%$, Kegiatan Belajar 5 dengan pokok bahasan Hukum Islam mencapai 80.12\%, Kegiatan Belajar 6 dengan pokok bahasan Sejarah Rasulullah SAW, di Mekah mencapai $81.93 \%$.

Berdasarkan kriteria yang digunakan bahwa nilai $>50 \%$ dikategorikan mudah. Disimpulkan bahwa tingkat keterbacaan modul Pendidikan Agama Islam (PAI) yang dikembangkan dalam penelitian dikategorikan mudah dalam arti siswa yang menggunakan mengerti isi bacaan. Berdasarkan hasil ujicoba pretest diperoleh skor rata-rata 70.11. dan skor rata-rata hasil posttest sebesar 83.56. Rata-rata kenaikan sebesar 13.45 Hasil ini menyatakan bahwa modul pendidikan agama Islam (PAI) yang dikembangkan dapat meningkatkan kemampuan siswa.

Hasil uji-t menunjukkan bahwa terdapat perbedaan dan peningkatan hasil belajar antara sebelum menggunakan modul dan sesudah menggunakan modul. Perbedaan tersebut juga menunjukkan bahwa modul yang dikembangkan terbukti lebih efektif. Hasil analisis uji-t menunjukkan perbedaan yang signifikan baik dengan taraf signifikansi 0,05. Diperoleh nilai $\mathrm{p}(\mathrm{t}$ hitung) sama dengan 0,000., karena $\mathrm{p}$ (t hitung) lebih kecil dari alfa 5\%, maka dapat disimpulkan bahwa terdapat perbedaan yang signifikan antara hasil belajar pada mata pelajaran Pendidikan Agama Islam (PAI) sebelum dan sesudah menggunakan modul.

Peneliti juga melakukan wawancara dengan salah seorang guru mata pelajaran Pendidikan Agama Islam (PAI) di SMA Negeri 1 Wangi-wangi mengatakan bahwa paket modul pendidikan agama Islam (PAI) 
untuk siswa Kelas X SMA Negeri 1 wangiwangi ini, memudahkan dalam menjelaskan materi, maupun dalam proses pembelajaran. Dalam modul ini di samping susunan materinya yang sistematis, juga dilengkapi dengan panduan bagi guru dan petunjuk bagi siswa. Modul ini dilengkapi dengan pembagian materi yang diajarkan secara konvensional dan secara mandiri sangat jelas. Dari segi ukuran dan desain serta peletakan gambar baik di cover maupun pada isi modul sudah bagus.

\section{Pembahasan}

Penelitian dan pengembangan dalam pembahasan ini, peneliti menguraikan nama produk, karakteristik produk, kelebihan produk dan kekurangan produk, untuk memberikan kejelasan dan posisi produk yang dikembangkan dalam penelitian ini, yakni sebagai berikut:

Pertama nama produk; nama produk dari hasil penelitian dan pengembangan ini adalah Paket Modul Cetak Mata Pelajaran Pendidikan Agama Islam (PAI) untuk siswa semester 1 (ganjil) kelas X SMA Negeri 1 Wangi-wangi. Paket modul cetak ini terdapat enam pokok bahasan atau enam kegiatan pembelajaran yaitu:

(1) Manusia dan Perannya di Bumi, (2) Perilaku Ikhlas dalam Beribadah, (3) Sifat Allah dalam Asma'ul Husna, (4) Perilaku Husnuzzan, (5) Hukum Islam, dan (6) Sejarah Rasulullah SAW, di Mekah.
Kedua, karakteristik produk; paket modul yang dikembangkan oleh peneliti berbentuk cetak dengan spesifikasi sebagai berikut:

Kemasan : Buku dengan softcover

Penjilitan : Menggunakan lem

Kertas

a. Isi: HVS 80 gram

b. Cover/ Kulit : Photo Paper 120 gram, Glossy- Dove

Huruf

a. Isi: Times New Roman, 12 pt, Open Sans

b. Cover/ Kulit : Open Sans

Warna : Full Colour

Ukuran : Kuarto (Portrait)

Ketiga, kelebihan produk; kelebihan paket modul cetak mata pelajaran Pendidikan Agama Islam (PAI) untuk siswa sementer 1 (Ganjil) kelas $\mathrm{X}$ ini adalah menampilkan materi Pendidikan Agama Islam (PAI) dengan bahasa yang mudah dan tampilan gambar yang menarik. Penjabaran materi dibuat seringan mungkin tanpa mengurangi kedalaman materi. Kegiatan belajar yang menarik di dalam modul, meminimalisir kebosanan belajar siswa dalam mempelajari materi modul. Ukuran modul yang tidak terlalu besar memudahkan siswa untuk membawanya dan mempelajarinya di mana saja dan kapan saja.

Keempat, kekurangan produk; adapun kekurangan yang dimiliki paket modul cetak mata pelajaran pendidikan agama Islam (PAI) ini adalah (1) Produk hanya terbatas pada materi semester pertama, sehingga ketika siswa masuk pada semester lanjutan dimungkinkan mengalami keterbatasan buku ajar. (2). Produk juga belum memuat soal yang banyak terutama pada latihan, 
karena dimungkinkan akan dikembangkannya lembar kerja siswa (LKS).

\section{KESIMPULAN}

Berdasarkan hasil penelitian dan pengembangan paket modul cetak mata pelajaran Pendidikan Agama Islam (PAI) untuk siswa kelas X SMA Negeri 1 Wangi-wangi, Kabupaten Wakatobi dapat disimpulkan bahwa modul sudah sangat baik, bahkan ada beberapa komponen modul yang sudah sangat baik dan perlu di pertahankan, tetapi peneliti juga menyadari bahwa memang masih ada komponen modul yang perlu diperbaiki dan dikembangkan terus. Hal ini dapat dilihat dari 4 (empat) uji kelayakan dan 1 (satu) uji efektivitas yang dilakukan yaitu : uji kelayakan ahli yakni ahli materi (Expert Matter) dan ahli media (Expert Media), uji kelayakan siswa, uji keterbacaan, serta uji efektivitas dengan melakukan tes.

Dari segi efektivitas modul cetak mata pelajaran pendidikan agama Islam untuk siswa kelas X SMA Negeri 1 Wangi-wangi, sudah dapat dikategorikan efektif. Hal ini berdasarkan data yang diperoleh dari hasil belajar siswa yang mengalami peningkatan. Di mana nilai awal ratarata pada pretest sebesar 70.11, menjadi 83.56, pada hasil posttest. Hal ini menunjukkan hasil pembelajaran siswa mengalami peningkatan secara signifikan yakni sebesar 13, 45. Perbedaan tersebut juga menunjukkan bahwa modul yang dikembangkan terbukti lebih efektif. Hasil analisis uji-t menunjukkan perbedaan yang signifikan baik dengan taraf signifikansi 0,05. Diperoleh nilai $\mathrm{p}$ (t hitung) sama dengan 0,000 ., karena $\mathrm{p}$ (t hitung) lebih kecil dari alfa 5\%, maka dapat disimpulkan bahwa terdapat perbedaan yang signifikan antara hasil belajar Pendidikan Agama Islam (PAI) sebelum dan sesudah menggunakan modul.

Secara keseluruhan dapat disimpulkan bahwa modul cetak mata pelajaran pendidikan agama Islam (PAI) untuk siswa kelas X SMA Negeri 1 Wangi-wangi yang dikembangkan sudah masuk pada kategori sangat baik, di mana modul sudah layak dan efektif untuk digunakan dalam pembelajaran. Sebagai bagian yang tak terpisahkan dalam penelitian dan pengembangan ini, peneliti menguraikan beberapa komponen yang perlu dilengkapi dalam produk sebagai berikut :

Pertama, modul mata pelajaran pendidikan agama Islam (PAI) yang dikembangkan ini, sebatas pada semester ganjil untuk siswa kelas X SMA, maka perlu dikembangkan modul dengan pokok bahasan atau topik untuk semester genap, serta mata pelajaran lainya.

Kedua, keterbatasan materi semester genap pada modul dan buku mata pelajaran pendidikan agama Islam (PAI), maka modul cetak yang dikembangkan perlu diperbanyak sesuai dengan kebutuhan dan kemampuan sekolah, agar dapat dibagikan keseluruhan siswa.

Ketiga, modul apabila ingin digunakan secara oneline atau menggunakan teknologi informasi dan komunikasi yang berkembang saat ini, maka modul harus dirubah ke PDF agar bisa digunakan dalam pembelajaran oneline.

Keempat, modul dapat dijadikan sebagai salah satu alternatif sumber belajar terutama dalam belajar mandiri. 


\section{DAFTAR REFERENSI}

Abu Syairi, Khairi. Jurnal: Dinamika Ilmu, Vol.13. No. 1, Juni 2013.

A. Pribadi, Benny, Langkah Penting Merancang Kegiatan Pembelajaran yang Efektif dan Berjuakitas; Model Desain Sistem Pembelajaran, Penerbit Dian Rakyat, Jakarta, 2009.

B. Seels, Barbara dkk, Teknologi Pembelajaran: Definisi dan Kawasannya. terjemahan Dewi S. Prawiradilaga, Raphael Raharjo dan Yusufhadi Miarso (Jakarta: Unit Percetakan UNJ, 1994)

C. Budiono, Eko. Jurnal Pend. Jurusan Fisika FMIPA UNNES Indonesia, Vol. 4, No. 2, Juli 2006.

D. Jerome, Distributed Problem-based Learning: A study of Instructional Design Models, Methods and Tools Designers Use to Create Collaborative and Interactive Learning Environments. Capella University, 2013.

Gustafson, Kent L. and Robert Maribe Branch. Survey of Instructional Development Models. New York: Eric Clearinghouse on Information and Technology, Syracus University, 2002.

Hadiya, Izkar, dkk, Pengembangan Modul Pembelajaran Suhu dan Kalor Berbasis Masalah untuk SMA dalam UpayaMeningkatkan Minat Belajar Siswa, Jurnal Pendidikan Sains Indonesia, Vol. 03, No.01, 2015.
Haryati, Sri Research And Development $(R \& D)$ Sebagai Salah Satu Model Penelitian Dalam Bidang Pendidikan. Vol. 37 No. 1, 15 September 2012.

Ibrahim, Nurdin. Perspektif Pendidikan Terbuka Jarak Jauh: Kajian Teoritis dan Aplikasi. Jakarta: Bumi Aksara, 2010.

Jufni, Muhammad, dkk, Jurnal Administrasi Pendidikan Pascasarjana Universitas Syiah Kuala, Volume 3, ISSN : 23020156 , No. 4, November 2015.

Khoirudin, M. Pengembangan Modul Pembelajaran IPA Biologi Berbasis Ingkuiri Pada Materi Interaktif Antar Makhluk Hidup Dan Lingkungannya, Jurnal: BIOEDUKASI Vol. 7. P ISSN 2086-4701. No. 2. Nov. 2016.

Lailatul Mi'rojiyah, Fajar Pengembangan Modul Berbasis Multi Representasi pada Pelajaran Fisika di Sekolah Menengah Atas, Jurnal; Vol.1, ISSN: 978-6029286-21-2. 2016.

Miarso, Yusufhadi, Menyemai Benih Teknologi Pendidikan, (Jakarta: Kencana Prenada Group, 2009).

Mujiman, Haris, Belajar Mandiri: Pembelajaran dan Penerapan, UNS Press. Cet. I, Surakarta, 2011.

Mulyasa, E.. Kurikulum Berbasis Kompetensi. Jakarta: PT Remaja Rosda Karya, 2003.

Prawiradilaga, Dewi Salma, Prinsip Desain Pembelajaran. Jakarta: Kencana, 2009. 
Prinsip Disain Pembelajaran.

Jakarta: Kencana Prenada, 2009.

Prastowo, Andi. Panduan Kreatif Membuat Bahan Ajar Inovatif. Yogyakarta: Diva Press, 2015.

Purwanto, Aristo Rahadi, dan Suharto Lasmono. Pengembangan Modul. Jakarta: PUSTEKKOM DEPDIKNAS, 2007.

Rouf, Abd. Jurnal Pendidikan Agama Islam, Volume 03, Nomor 01, Mei 2015

Rowntree, Derek. Preparing Materials for Open, Distance, and Flexible Learning.(London: Kogan Page, 1994.

Sitepu, B.P. Penyusunan Buku Pelajaran. Jakarta: Verbum Publishing, 2006.

Sugiyono, Metode Penelitian Kuantitatif, Kualitatif, dan $R$ \& D. Bandung: Alfabeta, 2015.

Suparman, M. Atwi. Desain Instruksional. Jakarta: Universitas Terbuka, 2004.

Sri Lestari, Ambar Jurnal Al-Ta'dib: Pembuatan Bahan Ajar Berbasis Modul Pada Matakuliah Media Pembeajaran Dijurusan Tarbiyah STAIN Sultan Qaimuddin Kendari, Vol. 7 No. 2. JuliDesember, 2014

Tegeh, I Made dkk, Model Penelitian Pengembangan, Graha Ilmu, Cet. Pertama, 2014

Trianto, Mendesain Model Pembelajaran Inovatif- Progresif. Jakarta: Kencana Prenada Media Group, 2009. 